\title{
Occurrence of Philornis bella Couri in nestlings of Tyrannus melancholicus Vieillot (Tyranninae) in the municipal district of Seropédica, Rio de Janeiro
}

\author{
Hermes Ribeiro Luz ${ }^{1 *}$ \\ Bruno Pereira Berto ${ }^{2}$ \\ Ildemar Fereira ${ }^{2}$ \\ Rafaela Dias Antonini ${ }^{3}$ \\ André Felippe Nunes-Freitas ${ }^{3}$ \\ Gonzalo Efrain Moya Borja ${ }^{2}$ \\ ${ }^{1} \mathrm{PPG}$ em Parasitologia Veterinária \\ ${ }^{2}$ Departamento de Parasitologia Animal, Instituto de Veterinária \\ ${ }^{3}$ Laboratório de Ecologia Florestal e Biologia Vegetal, Instituto de Florestas \\ Universidade Federal Rural do Rio de Janeiro \\ BR 465, km 7, CEP 23890-000, Seropedica - RJ, Brazil \\ *Autor para correspondência \\ hermes@ufrrj.br
}

Submetido em 01/02/2011

Aceito para publicação em 27/06/2011

\section{Resumo}

Ocorrência de Philornis bella Couri em ninhegos de Tyrannus melancholicus Vieillot (Tyranninae) no distrito municipal de Seropédica, estado do Rio de Janeiro. Foram estudados cinco ninhegos de Tyrannus melancholicus Vieillot, 1819, com idades aproximadas variando entre nove $(\mathrm{n}=2)$ e doze dias $(\mathrm{n}=3)$ de vida entre os meses de julho a setembro de 2006. Foi retirado um total de 43 larvas, das quais 33 (76\%) se tornaram adultos, sendo posteriormente identificados como Philornis bella Couri, 1984. As regiões mais infestadas foram: asa (44\%), cabeça $(39,5 \%)$ e coxa (16,5\%). Durante o presente estudo não houve morte de nenhum dos ninhegos. Assim, este estudo teve como objetivo o primeiro registro de P. bella parasitando ninhegos de Tyrannus melancholicus.

Palavras-chave: Diptera, Miíases, Muscidae, Philornis, Tyrannidae

\section{Abstract}

Five nestlings of Tyrannus melancholicus Vieillot, 1819, between nine $(\mathrm{n}=2)$ and twelve days $(\mathrm{n}=3)$ old, were studied from July to September in 2006. A total of 43 larvae was collected, of which 33 (76\%) became adults and were identified as Philornis bella Couri, 1984. The most infested areas of the nestlings were the wings (44\%), head (39.5\%) and coxae (16.5\%). None of the nestlings died during the study. This is the first record of P. bella parasitizing nestlings of Tyrannus melancholicus.

Key words: Diptera, Myiasis, Muscidae, Philornis, Tyrannidae 


\section{Introduction}

Philornis Meinert, 1890, is a genus of Muscidae that is predominantly neotropical (COURI, 1983). Adults can usually be distinguished from other congeners by the following combination of characters: palpi slightly enlarged at apex; arista with long plumes; mesonotum usually quadrivittate; anepimeron hairy; postalar wall with a tuft of cilia; posterior spiracle with cilia; dorsocentral bristles 2+4; anal vein long; and third and fourth veins divergent, the latter a little bent towards the tip. The presence of hairs on the anepimeron and on the postalar wall can easily distinguish adults of Philornis from those of other muscid genera. According to Couri (1999), P. bella differs from other species of the genus by having the following: yellow antenna and palpi; yellowhaired cheeks; yellowish-brown mesonotum, with greyish pollinosity, and four brown vittae; abdomen with tergites 2 and 3 yellow; first sternite and genital segments yellow; hind tibia with 5-6 bristles on anterodorsal surface and 5-6 bristles anteroventral surface.

Apparently, the intimate association of Philornis flies with neotropical birds was first mentioned in Brazil in the middle of the seventeenth century by George Marcgrave (TEIXEIRA, 1982). The larvae of this genus can be free living on bird nests, with a coprophagous or semi-hematophagous habit, or live intradermally in nestlings, with a hematophagous habit (COURI, 1985). In Brazil, 29 species of Philornis have been recorded, and 10 species are known from the state of Rio de Janeiro (COURI; CARVALHO, 2005). According to Couri (1984), 23 species of Philornis are related to the nestlings of 75 bird species, and two cases are known for adult birds, which were reported by Macquart (1854) and Dodge and Atiken (1968). Teixeira (1999) reported parasitism by Philornis for 105 species of birds that belong to 32 families.

In this study, we present the first record of larvae of Philornis bella on nestlings of Tyrannus melancholicus Vieillot, 1819 (Aves, Tyrannidae), which was observed in the municipality of Seropédica, in the state of Rio de Janeiro.

\section{Materials and Methods}

The study was conducted from July to September of 2006 in the municipal district of Seropédica $\left(22^{\circ} 45^{\prime} 49^{\prime \prime} \mathrm{S}\right.$, 4341'19"W, 70m elevation).

The larvae were removed manually from different regions of the body and placed in sterile plastic containers that were covered with a fine mesh cloth. Dry grass and a thin layer of soil were placed in each container to allow pupariation and metamorphosis. After the adult forms of diptera emerged, cotton moistened with water was placed inside each container to maintain the humidity of the environment.

The adults were allowed to die naturally so their life expectancy could be estimated. After death, the adults were stored in $70^{\circ} \mathrm{GL}$ ethanol and identified.

\section{Results and Discussion}

From July to September of 2006, five nestlings of Tyrannus melancholicus were found, which were approximately nine $(\mathrm{n}=2)$ and twelve days $(\mathrm{n}=3)$ old. A total number of 43 larvae were collected during this time, of which $33(76 \%)$ became adults and were identified as Philornis bella Couri, 1984.

At this time there was no record of P. bella parasitizing nestlings of Tyrannus melancholicus. According to Teixeira (1999), only two species of Philornis, P. downsi (Dodge and Aitken, 1968) and $P$. trinitensis (Dodge and Aitken, 1968), were known to be parasites of the nestlings of this species.

We observed a higher concentration of larvae in the uropygium, wings and tails of the nestlings. Possati et al. (2001) mentioned that the larvae of $P$. bella found in nestlings of $P$. sulphuratus were collected from the wings, head, upper back and near the cloacae, but did not mention which region was parasitized the most. In a study by Luz et al. (2007), the authors mention several areas with parasites, and the most infested regions were the wings and uropygium. Thus, we believe that parasitism in these regions lowers the chance that the host will prey on the larvae. 
We did not observe any feces or other organic matter inside the nest that could explain the parasitism. The larvae of $P$. bella are subcutaneous (biting), feed on blood, and are commonly found in birds that keep clean nest (HIGGINS et al., 2005). According to Guimarães and Papavero (1983), these muscidae deposit their eggs directly on the young or their nests. As for any debilitating effect caused by the parasitism in the present study, no nestlings died. The number of larvae (mean of 8.6 larvae per nestling) was probably not sufficient to cause death. However, Smith (1968) mentions that seven larvae would be enough to cause a debilitating effect on a nestling. Higgins et al. (2005) also mentioned that the effect is debilitating and described the death of a nestling of $S$. slelorum due to severe parasitism by larvae of Philornis.

Possati et al. (2001) mentioned that the average number of larvae found on nestlings of $P$. sulphuratus was seven and that all the nestlings survived. It is important to note that the removal of some larvae for identification may directly influence the recovery of the hosts so they do not die. However, we do not have sufficient data to conclude that this procedure prevented the death of the studied nestlings. According to Aguilar et al. (1999), after collecting some larvae of Philornis, which were living in nestlings of $L$. euleri, all of the nestlings died, and the following year, in a new study with the same species, the larvae were not removed and all of the nestlings survived. In another study, Luz et al. (2007) reported that the survival of nestlings of $X$. cinerea could be related to other factors, and not only the number of larvae parasitizing a nestling. Thus, we believe that the debilitating effect on hosts may be linked to two factors: age of the nestling $\mathrm{x}$ number of parasites and the behavior of parents while feeding a nestling. It is also possible that different host species have different resistances against this kind of parasite. Based on a study by Smith (1968), seven larvae would be enough to cause the death of a host bird, and a study by Couri (1985), where 32 larvae of a Philornis sp. in a nestling of Pitangus sulphuratus did not kill the bird, we can infer the possibility of host species that are resistant to this type of parasite. Thus, additional studies about the factors that cause the debilitating effect on the hosts are needed, as well as studies about the biology of these parasites and their hosts. The goal of this study was to report the first record of $P$. bella parasitizing nestlings of T. melancholicus.

\section{Acknowledgments}

We thank André César Lopes da Silva and Rodrigo Rocha Barbosa for helping identify Philornis bella, and Ursula Brazil for helping with the translation.

\section{References}

AGUILAR, T. M.; LEITE, O. L.; MARINI, M. A. Biologia da nidificação de Lathrotriccus euleri (Cabanis, 1968) (Tyrannide) em fragmentos de mata de Minas Gerais. Revista Brasileira de Ornitologia, São Paulo, v. 7, p. 125-133, 1999.

COURI, M. S. Descrição de seis espécies novas de Philornis Meinert, 1890 (Diptera, Muscidae, Cyrtoneurininae). Revista Brasileira de Biologia, São Carlos, v. 43, n. 3, p. 297-310, 1983.

COURI, M. S. Notes and description of Philornis flies (Diptera, Muscidae. Cyrtoneurininae). Revista Brasileira de Entomologia, Curitiba, v. 28, n. 4, p. 473-490, 1984.

COURI, M. S. Considerações sobre as relações ecológicas das larvas de Philornis Meinert, 1890 (Diptera, Muscidae) com aves. Revista Brasileira de Entomologia, Curitiba, v. 29, n. 1, p. 17-20, 1985.

COURI, M. S. Myiasis caused by obligatory parasites Ia. Philornis Meinert (Muscidae). In: GUIMARÃES, J. H.; PAPAVERO, N. (Eds). Myiasis in man and animals in the Neotropical Region Bibliographic database. São Paulo: FAPESP, Editora Plêiade, 1999. p. $51-70$

COURI, M. S.; CARVALHO, C. J. B. Diptera Muscidae do estado do Rio de Janeiro (Brasil). Biota Neotropica, Campinas, v. 5, n. 2, p. 205-222, 2005.

DODGE, H. R.; AITKEN, T. H. G. Philornis flies from Trinidad (Diptera: Muscidae). Journal of Kansas Entomological Society, Lawrence, v. 41, p. 134-154, 1968.

GUIMARÃES, J. H.; PAPAVERO, N. As míases na região neotropical. Revista Brasileira de Zoologia, Curitiba, v. 1, n. 4, p. 239-416, 1983.

HIGGINS, B. F.; LOPES, L. E.; SANTANA, F. H. A.; COURI, M.; PUJOL-LUZ, J. R. Sobre a ocorrência de Philornis angustifrons e $P$. deceptiva (Diptera, Muscidae) em ninhos de Suiriri affinis e S. islerorum (Aves, Tyrannidae), no cerrado do Distrito Federal, Brasil. Revista Entomologia y Vectores, Rio de Janeiro, v. 12, n. 1, p. 127-131, 2005.

LUZ, H. R.; FERREIRA, I.; COURI, M. S. Ocorrência de larvas de Philornis deceptiva (Dodge \& Aitken, 1968) (Diptera: Muscidae) na Maria-branca, Xolmis cinerea (Vieillot, 1816) (Aves: Tyrannidae), no município Seropédica,Rio de Janeiro, Brasil. Revista Lundiana, Belo Horizonte, v. 8, n. 2, p. 153-154, 2007. 
MACQUART, J. Notice sur une nouvelle espèce d'Aricie, diptère de la tribu des Anthomyzides. Annales de la Société Entomologique, Paris, v. 3, n. 1, p. 657-660, 1854.

POSSATI, M.; LEMOS, M.; PINTO, C.; MELLO, R. P.; GUERIM, L.; SERRA-FREIRE, N. M. Ocorrência de Philornis bella Couri, 1984 em Pitangus sulphuratus (Sclater, 1888) (Aves Tyrannidae) em Niterói estado do Rio de Janeiro, Brasil. Revista Entomologia y Vectores, Rio de Janeiro, v. 8, n. 3, p. 391-394, 2001.

SMITH, N. The advantage of being parasitized. Nature, New York, v. 219, n. 5155, p. 690-694, 1968.

TEIXEIRA, D. M. As fontes do paraíso - um ensaio sobre a Ornitologia no Brasil holandês (1624-1654). Revista Nordestina de Biologia, João Pessoa, v. 7, n. 1/2, p. 1-149, 1982.

TEIXEIRA, D. M. Myiasis caused by obligatory parasites. General observations on the biology of species of the genus Philornis Meinert, 1890 (Diptera, Muscidae). In: GUIMARÃES, J. H.; PAPAVERO, N. (Eds). Myiasis in man and animals in the Neotropical Region - Bibliographic database. São Paulo: FAPESP, Editora Plêiade, 1999. p. 71-96. 